\title{
Analysis and experiments of the effect of reinforcement of wood beam using carbon fiber reinforced polymer against bending strength
}

\author{
Torang Sitorus ${ }^{1, *}$, Silvy Desharma ${ }^{2}$ \\ ${ }^{1}$ Department of Civil Engineering, Faculty of Engineering. Universitas Sumatera Utara, Medan, Indonesia \\ ${ }^{2}$ Department of Civil Engineering, Faculty of Engineering. Universitas Sumatera Utara, Medan, Indonesia
}

\begin{abstract}
Flexural reinforcement on wood beams is intended to increase the maximum load capacity that can be supported by wood beams until they are collapse. One of the most widely used resilient reinforcements currently used is reinforcement using Carbon Fiber Reinforced Polymer (CFRP) which is a combination of high strength with light weight material. This reinforcement is intended for historical buildings that need more load capacity that can be supported due to changes in building function, or the increase of the load on the building. The purpose of this research is to know the effect of reinforcement of wood beams with CFRP and variation of length of reinforcement to flexible strength of wood beams, and beam behavior reinforced with CFRP due to loading. Structural beam testing using mahogany logs with cross sectional size $75 \times 100 \mathrm{~mm}^{2}$ along $2 \mathrm{~m}$ consisting of 4 types of samples with each type consists of 2 pieces of sample. The first sample was a wood beams without reinforcement, the second sample was a wood beams with a reinforcing length of $1 / 4$ spans in the middle, a third sample was a wood beams with a reinforcing length $3 / 4$ spans in the middle, and a fourth sample was a wood beams with retrofitting along the length of the span. From the test it is found that the maximum load increase that can be supported by the sample with the length of reinforcement $1 / 4$ span, $3 / 4$ span, and along the span has increased the maximum load respectively that is $4.393 \%$, $37.340 \%$, and $48.323 \%$ compared to wood beams without reinforcement. The average damage occurring in samples with CFRP is debonding failure.
\end{abstract}

\section{Introduction}

Wood as a construction material has long been used by the Indonesia people. It can be seen from the historical buildings, adat houses, and the other traditional buildings in Indonesia where the majority of building materials are made of wood ${ }^{[1]}$. As time goes by, old historical buildings which use wood as building materials should be reviewed their structural strength because of the decrease in the wood strength and the building change of function without the change in their original shape ${ }^{[2]}$. Therefore, in order to cope with these problems, it is necessary to have accurate wood strength materials which do not change the shape of the building construction, but at the same time they can improve the strength of the wood beams so that they will be effective, practical, and eficient ${ }^{[3]}$.

Today, a lot of building constructions use carbon fibers as the composite materials to strengthen building constructions ${ }^{[4]}$. Carbon fiber is a combination of height strength with light weight, especially the carbon which is stronger than steel and very light. Besides that, carbon fiber has the capacity to bear high temperatureand has the moisture characteristic (the characteristic of maintaining its condition). It constitutes a composite material which contains binding and reinforcing. Reinforcement provides strength and inflexibility, while binding keeps strength in the fixed position.This carbon fibercan be found in Carbon Fiber Reinforced Polymer (CFRP) ${ }^{[5]}$.CFRP is a composite material which has light physical nature and the other advantages such as its tensile strength higher than reinforcement steel sheets of 2,800 $\mathrm{MPa}$, it can endure corrosion because it is made of non-metallic material, its elastic modulation is close to steel, and it is flexible although it can become inflexible when it is given epoxy $^{[6]}$.

\section{Literature Review}

\subsection{General}

The basic concept of implementing Carbon Fiber Reinforced Polymer (CFRP) in wood is that the majority

* Corresponding author: torang.sitorus@usu.ac.id 
of historical buildings in Indonesia use wood as their main material. As time goes by, there has been the change in their structural function which needs the capacity to carry heavier load. Overloading in the long run will relatively cause curvature on wood beams so that strengthening is needed to cope with the damage in the structure. The popular strengthening method today by using CFRP which is adhesive by using epoxy on the wood beams so that they become composite unit. Therefore, we need to know the characteristic features of the structural materials related to it.

\subsection{Wood}

Wood is a forest product and the source of natural wealth as a raw material which has to be processed so that the lumber is obtained by processing logs to become lumber such as plank, lath, and the other shapes to be used as building construction. Wood has physical and mechanical properties. It physical property is a quantitative one and its endurance against environmental influence. Meanwhile, its mechanical properties are closely related to its strength.One of the wood mechanical properties is flexble.

Flexible reinforcement is strength of wood endurance against any forces which attempt to bend wood. The load on wood beam which has been carried for a long time will increase its curvature as the effect of the decrease in the tension which will eventually bring about collapse. The behavior of the increase in curvature is known as creep.Based on SNI 03-3959-1995, the method of testing wood flexible strength in the Laboratory, the flexible strength is calculated by using the following formula:

$$
f_{b}=\frac{3 P_{m a k s} L}{2 b h^{2}}(M P a)
$$

Based on SNI 03-3975-1995, the method of testing wood flexible strength of Structural Construction, the flexible reinforcement of structural beam is calculated by using the formula as following formula:

$$
f_{b}=\frac{P_{\text {maks }} \times a}{2 \times w}
$$

\subsection{Carbon Fiber Reinforced Polymer (CFRP)}

CFRP is a type of FRP which has the most superior strength, compared to the other types of FRP such as glass and Aramid which as usually used to strengthen structural in a construction. It is a composite polymer material which is strengthened by carbon fibers which today become an alternative material which is more popular for strengthening and improving civil infrastructure system since it has extraordinary strength with light and flexible properties.Its Sika CarboDur Plate is an S 512 type with $50 \mathrm{~mm}$ in width, $1.2 \mathrm{~mm}$ in thickness, and $168 \mathrm{kN}$ in tensile strength.

\subsection{Epoxy Resin Substance (Sikadur - 30)}

Epoxy Resin Substance used to adhesive is Sikadur-30, produced by PT. Sika Indonesia. It is structural adhesive of a thixotropic two-component as the result of combining epoxy resin and the result of the combination of epoxy resin and specific crack filler, designed to normal temperature between $+8^{\circ} \mathrm{C}$ and $+35^{\circ} \mathrm{C}$. Sekadur -30 consists of two adhesive components (epoxy resin); they are Component $\mathrm{A}$ and Component $\mathrm{B}$ which are used by using the Ratio of $\mathrm{A}: \mathrm{B}=3: 1$.

\subsection{Deflection on Beam}

The tension on the beam is proportional with curvature of deflective curves. The curvature in the flexible moment in the beam is stated in the following formula which is known as deflective-moment equation (Gere and Timoshenko, 2000) :

$$
\kappa=\frac{1}{\rho}=\frac{M}{E I}
$$

According to Gere and Timoshenko (2000), the area of maximum flexibility occurs as the effect of concentrated loading with the distance of a from the foothold is:

$$
\delta_{m a k s}=\frac{P a}{24 E I}\left(3 L^{2}-4 a^{2}\right)
$$

If $\mathrm{P}=1 / 2 \mathrm{P}$, the formula of the flexibility is:

$$
\delta_{m a k s}=\frac{P a}{48 E I}\left(3 L^{2}-4 a^{2}\right)
$$

\subsection{Composite Beam}

Composite beam is a beam in the combination of two or more types of different components which is aimed to strengthen the main compiler which is weaker but has economical value that is more inexpensive, or by considering the self-weight of component in which the specific gravity of reinforcing component is bigger and its material is stronger.

The formula of flexible tension of composite beam, based on the formula of curvature and Hooke law, is as follows:

$$
\begin{gathered}
\sigma_{x 1}=-\frac{M y E_{1}}{E_{1} I_{1}+E_{2} I_{2}} \\
\sigma_{x 2}=-\frac{M y E_{2}}{E_{1} I_{1}+E_{2} I_{2}}
\end{gathered}
$$

This formula is known as flexibility formula for composite beam which gives flexible tension in component 1 and component 2 .

\subsection{Transformation Section Method}

Transformation Section Method is an alternative procedure for analyzing flexible tension in composite 
beam. This method consists of transformation section in composite beam which becomes equivalent section of imaginary beam that consists of only one component which is called transformation section.

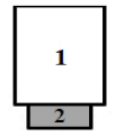

(a)

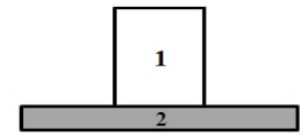

(b)
Fig. 1. Composite beam with two components: (a) actual section and (b) transformation section

Modular Ratio (n) is used in transformation section as the factor of width multiplier (paralleled dimension of neutral axis) from the section which will be transformed to the main section. The modular ratio based on Youngs Modulii of Elasticity is :

$$
n=\frac{E_{2}}{E_{1}}, \text { where } E_{2}>E_{1}(\text { so that } \mathrm{n}>1)
$$

\section{Research Methodology}

The research used experimental analytical method. It was conducted in the Concrete Laboratory of Civil Engineering, University of Sumatera Utara, in the Mechanical Test Laboratory of Forest Product, University of Sumatera Utara, in the Structure Laboratory, Politenik Negeri Medan for testing wood physical and mechanical properties, and in the Structure Laboratory of Civil Engineering Graduate School, University of Sumatera Utara for testing theflexible strength of wood beams.

The testing object for the testing of flexible stength in structural size used eight samples of mahogany wood of $75 \times 100 \times 2,000 \mathrm{~mm}$, as it could be seen in Table 1below:

Table 1. Testing Object for Testing Flexible Strength of Wood Beams

\begin{tabular}{|c|c|c|c|}
\hline No. & Types of Testing Object & $\begin{array}{l}\text { Code of } \\
\text { Testing } \\
\text { Objects }\end{array}$ & $\begin{array}{l}\text { Number } \\
\text { of } \\
\text { Testing } \\
\text { Objects }\end{array}$ \\
\hline 1 & $\begin{array}{c}\text { Wood beam without CFRP } \\
\text { reinforcement }\end{array}$ & $\mathrm{BKU}$ & 2 \\
\hline 2 & $\begin{array}{l}\text { Wood beam with CFRP } \\
\text { reinforcement along the span }\end{array}$ & $\mathrm{BKCP}$ & 2 \\
\hline 3 & $\begin{array}{c}\text { Wood beam with CFRP } \\
\text { reinforcement along } 3 / 4 \text { of middle } \\
\text { span } \\
\end{array}$ & BKCT & 2 \\
\hline 4 & $\begin{array}{l}\text { Wood beam with CFRP } \\
\text { reinforcement along } 1 / 4 \text { of } \\
\text { middle span }\end{array}$ & $\mathrm{BKCS}$ & 2 \\
\hline & Total of Testing Objects & & 8 \\
\hline
\end{tabular}

This testing was based on SNI 03 which began with the testing of wood physical and mechanical properties, followed by the testing of flexible strength of beams in structural size. Flexible strength model of wood beam in structural size could be seen in Figure 2 below.

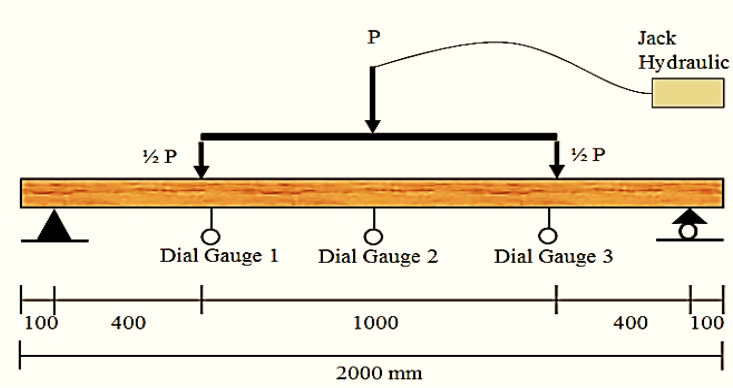

Fig. 2. Flexible Strength Testing of Wood Beam in Structural Size

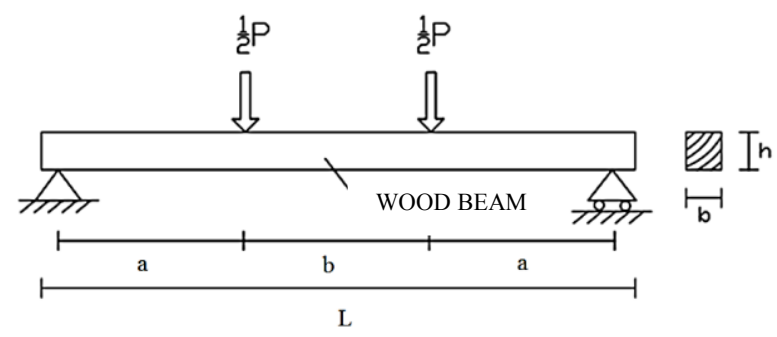

Fig. 3. Testing Model of Wood Beam without Reinforcement

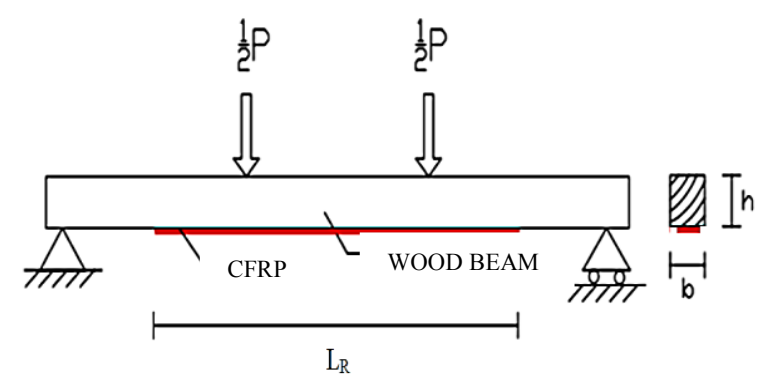

Fig. 4. Testing Model of Wood Beam with Reinforcement along $L_{R}$ of the Span

After maximum load was obtained from the testing, flexible tension of the testing object, wood beam, was calculated by using the equation below:

$$
f_{b}=\frac{P_{\text {maks }} \times a}{2 \times w}
$$

The testing object, wood beam, with CFRP reinforcement, the formula of beam normal tension in composite beam was

$$
f_{b 1}=\frac{M y}{I_{t}} ; f_{b 2}=\frac{M y}{I_{t}} n
$$

in which $f_{b 1}$ was normal tension in component 1 and $f_{b 2}$ was normal tension in component 2 , or the component transformed to component 1 .

Maximum deflection as the result of maximum load was calculated by the following formula:

$$
\delta_{\text {maks }}=\frac{P a}{48 E I}\left(3 L^{2}-4 a^{2}\right)
$$




\section{Results and Discussion}

\subsection{The Testing Result of Wood Physical and Mechanical Properties}

Table 2. Testing Result of Wood Physical and Mechanical

\begin{tabular}{ccc}
\multicolumn{3}{c}{ Properties } \\
\hline Types of Research & $\begin{array}{c}\text { Research } \\
\text { Result }\end{array}$ & Unit \\
\hline Water Content & $10.087 \%$ & $\%$ \\
\hline Specific Gravity & 0.981 & \\
\hline Parallel Tensile Strength & 60.436 & $\mathrm{MPa}$ \\
\hline Flexible Strength & 78.618 & $\mathrm{MPa}$ \\
\hline Parallel Compressive Strength & 25.15593 & $\mathrm{MPa}$ \\
\hline Elasticity Modules & 11930.405 & $\mathrm{MPa}$ \\
\hline
\end{tabular}

According to the Procedure of PKKI (Wood Construction Planning, 2002), sorting-based reference strength is mechanically taken according to flexible elasticity modules.It could be seen from Table 3 above that, according to the procedure of PKKI (2002), the wood used with elasticity modules of $11930.405 \mathrm{Mpa}$ includes the wood with E12 quality code.

\subsection{Testing Result of Flexible Strength of Beam in Structural Size}

The graph of load toward curvature from the result of the sample testing of flexible strength in structural size could be seen in the following graph:

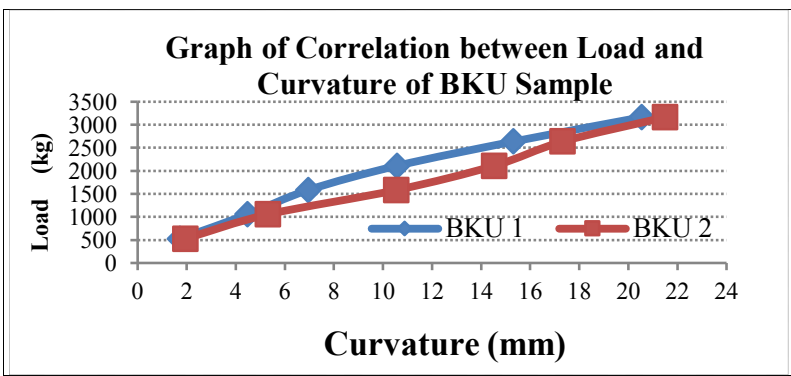

Fig.5. Graph of Correlation between Load and Curvature of BKU Sample

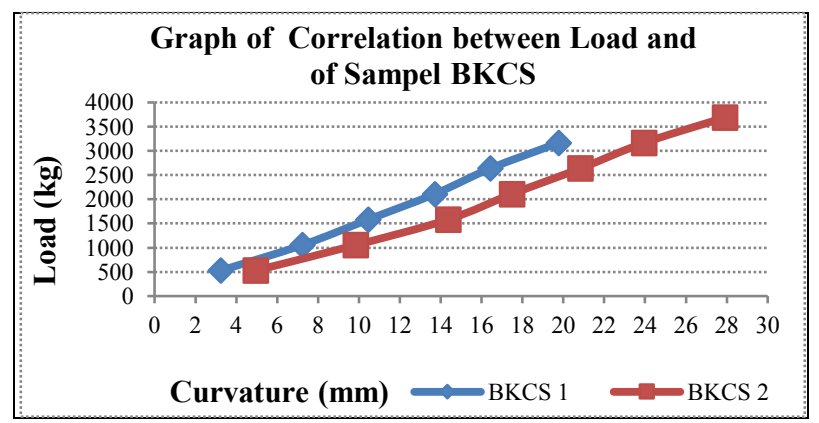

Fig.6. Graph of Correlation between Load and Curvature of BKCS Sample

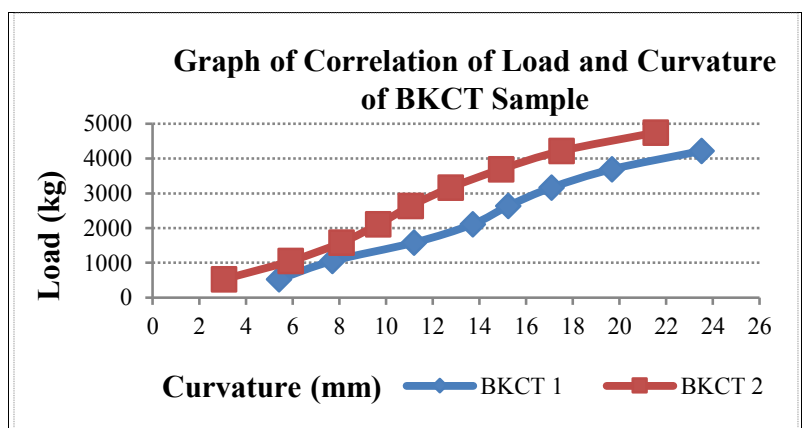

Fig. 7. Graph of Correlation between Load and Curvature of BKCT Sample

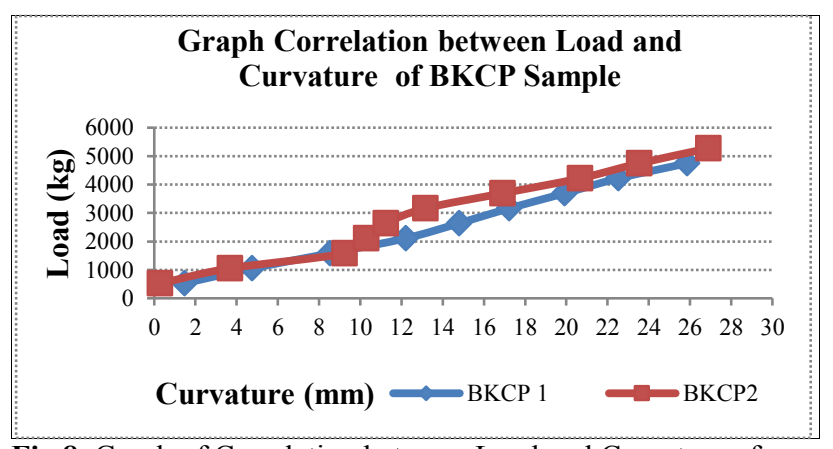

Fig.8. Graph of Correlation between Load and Curvature of BKCP Sample

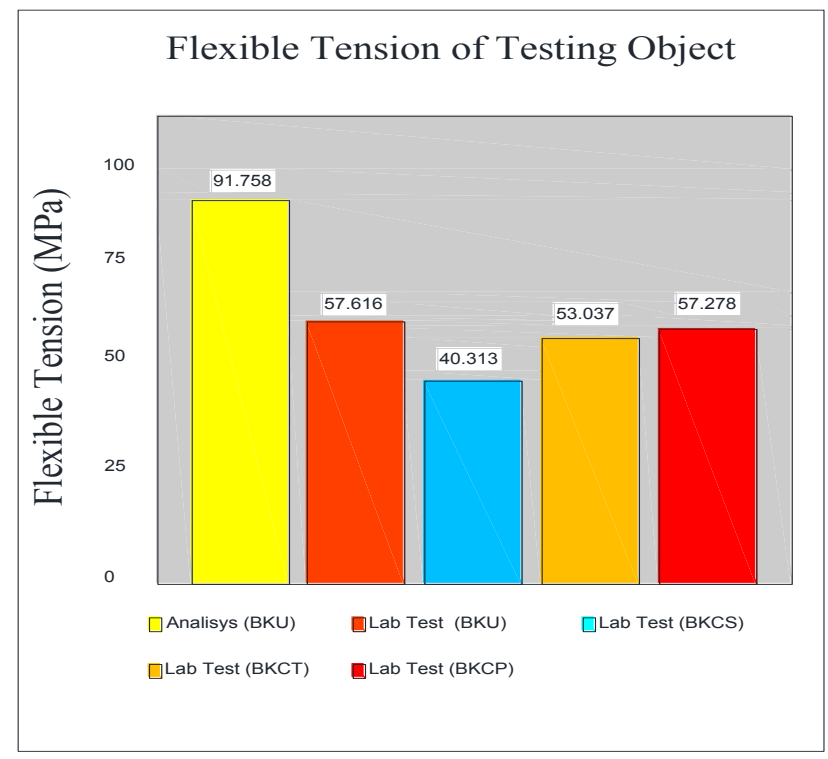

Fig.9. Graph of Flexible Tension of Testing Object 


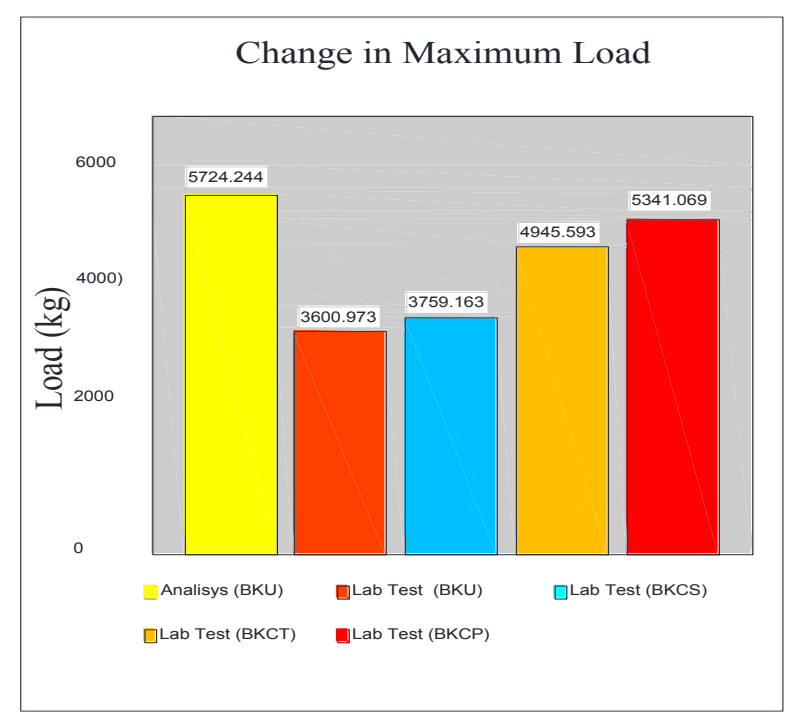

Fig. 10. Graph of the Change in Maximum Load of Testing Object

\subsection{Discussion on Testing Result}

In the BKU sample, wood beam without reinforcement broke when the average maximum curvature was 37.642 $\mathrm{mm}$ with the average maximum load of $3600.973 \mathrm{~kg}$, and the average flexible tension of 57.616 MPa. This wood beam was cracked in BKU sample 1 and broken in BKU sample 2 with oblique fracture. In BKU sample 1, there was a knur, while in BKU sample 2 there was no defect.

In BKCS sample, wood beam with the length of reinforcement of $500 \mathrm{~mm}$, there was the average maximum curvature of $28.176 \mathrm{MPa}$. In BKCS sample1, there was a crack in wood beam, while in BKCS sample 2 there was debonding failure in the left side of CFRP, followed by stringy fracture mostly in the middle span of wood beam.

In BKCT sample, wood beam with the length of reinforcement of $1,500 \mathrm{~mm}$, there was the average maximum curvature of $37.069 \mathrm{~mm}$ with the average maximum load of $4945.593 \mathrm{~kg}$, and flexible tension of $53.037 \mathrm{MPa}$. The damage was caused by the loading debonding failure, followed by oblique crack and the fracture of wood beam.

In BKCP sample, wood beam with reinforcement along the span of $2,000 \mathrm{~mm}$, there was the average maximum curvature of $40,033 \mathrm{~mm}$ with the average maximum load of 5341.069, and the average flexible tension of 57.278 MPa. In BKCP sample 1, there was oblique crack in wood beam, while in BKCP 2, there was debonding failure, followed by fringy fracture in wood beam.

The maximum load which could be carried by BKCS, BKCT, and BKCP samples increased 4.393\%, 37.340\%, and $48.323 \%$ respectively, compared with the maximum load of BKU.It could be concluded that there was the increase in maximum load by the existence of reinforcement and the longer reinforcement in wood beams.

The increase in maximum load could be carried by $\mathrm{BKCS}, \mathrm{BKCT}$, and BKCP samples.

\section{Conclusion}

Based on the testing of third point loading, it was found that the increase in the maximum load of wood beam at the length of reinforcement of $1 / 4$ Span, $3 / 4$ span, and the span length compared to wood beams without reinforcement at $4.393 \%, 37.340 \%$, and $48.323 \%$ respectively.Wood beam reinforced by using CFRP would increase its maximum load, along with the increase in the length of reinforcement of CFRP.The failure of wood reinforcement using Carbon Fiber Reinforced Polymer (CFRP) was partly caused by the loosing bond between CFRP and wood beam which was called debonding failure.

The authors gratefully acknowledge that the present research is supported by Ministry of Research and Technology and Higher Education Republic of Indonesia. The support is under the research grant BP-PTN USU of Year 2018 Contract Number $\mathrm{XXX} / \mathrm{XXX}$.

\section{References}

1. Bowyer JL, Shmulsky R, Haygreen JG.2003. Forest Products and Wood Science An Introduction Fourth Edition. IOWA (US): IOWA State University Pr. Haygreen dan Bowyer, 1993.

2. Tsoumis, G. 1991.Science and Technology Wood. Structure, Properties, Utilization. Van Vostrand Reinhold Inc, New York (US).

3. Kollman, F. dan Cote, J. R. 1968.Principles of Woods Science and Technology I. Solid Wood, New York.

4. Brown, H.P., A.J. Panshin, dan C.G. Forsaith. 1952. Textbook of Wood Technology, II. McGraw -Hill Book Co, New York.

5. Brancusi,Constantin. 2016. On the role of CFRP reinforcement for wood beams stiffness, Jurnal Materials Science and Engineering. Januari 2015.

6. Khelifa, M., 2016. Experimental and numerical analysis of CFRP-strengthened finger-jointed timber beams, International Journal of Adhesion \& Adhesives, 68, 283-297 (2016).

7. Kollman, F. dan Cote, J. R. 1968. Principles of Woods Science and Technology I. Solid Wood, New York.

8. Pangestuti, Endah Kanti., Nuroji., Antonius. 2006. Pengaruh Penggunaan Carbon Fiber Reinforced Plate Terhadap Perilaku Lentur Struktur Balok Beton Bertulang, Pilar, 15, 86-94 (2016) [in Indonesian].

9. Badan Penelitian dan Pengembangan. 2002. Metode, Spesifikasi dan Tata Cara, Bagian : 13 Kayu, Bahan Lain-Lain. Jakarta : Departemen Permukiman dan Prasarana Wilayah [in Indonesian].

10. Baier, A. 2011. Method Statement Sika CarboDur Externally Bonded Reinforcement [pdf]. www.sika.com. Tanggal akses : 25 April 2017.

11. Gere, James M., dan Timoshenko, Stephen P., 2000. Mekanika Bahan Jilid 1, Edisi Keempat. Jakarta : Penerbit Erlangga [in Indonesian]. 
12. Gere, James M., dan Timoshenko, Stephen P., 2000. Mekanika Bahan Jilid 2,4. Jakarta : Penerbit Erlangga [in Indonesian]. 